\title{
改良レイノルズ応力方程式モデルによる障害物流れの乱流熱流れ解析*
}

須賀 一 彦*1

\section{Turbulent Heat Transfer Computations around a Square Obstacle Mounted on a Channel Wall by an Improved Second Moment Closure}

\author{
Kazuhiko SUGA*2 \\ *2 Toyota Central Research and Development Laboratories Inc., \\ Nagakute-cho, Aichi-gun. Aichi, 480-1192 Japan
}

\begin{abstract}
A new effort to improve the prediction of turbulence and heat transfer in the recirculating region behind an obstacle by a second moment closure is discussed. A novel rapid pressure-diffusion model is included in a low Reynolds number two-component-limit second moment closure. The higherorder GGDH for turbulent heat flux is employed for the thermal field computation. Encouraging results are obtained for both turbulence and heat transfer fields though some margins to be improved are still remained.
\end{abstract}

Key Words : Turbulence, Recirulating Flow, Heat Transfer, Pressure-Diffusion, Second Moment Closure

\section{1. 緒 言}

レイノルズ応力方程式中の圧力拡散項の重要性は, 近年になるまで十分に認識されてきたわけではない. Yao ら ${ }^{(1)}$ はNS（直接数值解析）によって矩形後縁の 後流を解析し, 循環渦内で圧力拡散項が非常に大きく なることを見出した．興味深いことにその分布はせん 断生成項を上回るということである. したがって, こ の効果を適切に表現できなければこの種の流れ場を正 確に予測できないと言うことになる. そのことが, 多 くの高次 RANS（レイノルズ平均 Navier-Stokes）モ テルがブラフ・ボティ後流の乱れ量の回復を正確に予 测できない(2)理由の一つと考えられる.

これまでにも圧力拡散項のモデル化は何度も試みら れてきた. Lumley ${ }^{(3)}$ は圧力拡散項中の三重相関項を 含む部分 (slow 項) を実現性条件の制約をかけること によりモテル化した. 結果的にはこの圧力拡散 slow 項は乱流拡散項のサブプロセスのように表現された. （圧力拡散項には，その他に歪速度を含む部分 (rapid 項) があることを忘れてはならない.）また，乱流境 界層流やチャネル乱流の $\mathrm{DNS}^{(4)}{ }^{(5)}$ がなされるように なって, 圧力拡散項が壁面近傍で散逸項と釣り合う働 きをすることが分かってから，これを考虑するために

* 原稿受付 2003 年 12 月 16 日，

*1 正員, (株) 豊田中央研究所 (- 480-1192 愛知県愛知郡長久 手町大字長湫字横道 41-1).

E-mail : k-suga@ mosk.tytlabs.co.jp
乱流エネルギのモデル式中に散逸率の二階勾配からな るモテル項 ${ }^{(6) ~(8)}$ が用いられた. 一方, レイノルズ応 力の不変量を用いて圧力拡散項をモテル化 ${ }^{(9)}$ する例も ある. いずれにしてもこれらのモデルは壁面近傍用に 設計され, かつ歪速度の効果を含んでいない.

したがって, 壁面から遠く離れた領域でも有効で, か つ歪速度の影響を含んだ圧力拡散の rapid 項のモテル については殆ど議論がなかった. しかし, 最近になって Yoshizawa $^{(10)}$ は数理統計理論に基づき歪速度の効果を 加えた圧力-速度相関のモデルを議論した. 著者 ${ }^{(11)} も$ 圧力速度相関テンソルのモデルに TCL(two-componet limit) 乱流条件等を適用して, 圧力拡散 rapid 項のモ デル化を行った. そして, 提案したモデル項を TCL $\mathrm{SMC}^{(9)}$ (second moment closure :レイノルズ応力方 程式モテル) に適用し, 矩形後縁流れやバック・ステッ プ流れでその有効性を議論している. 本研究ではその 圧力拡散 rapid 項のモデルを組み込んだ TCL SMC を さらに複雑な障害物流れ ${ }^{(12)}$ の乱流熱伝達の場に適用 し, 温度場を含めた場における有効性について議論し た. そこでは, 乱流熱流束モテルの比較についての議 論も合わせて行った.

\section{記号}

$a_{i j}$ : レイノルズ応力の無次元非等方度テンソ ル $\left[\overline{u_{i} u_{j}} / k-2 / 3 \delta_{i j}\right]$

$A ：$ レイノルズ応カのフラットネス・パラメー 
夕 $\left[1-\frac{9}{8}\left(A_{2}-A_{3}\right]\right.$

$A_{2}$ : レイノルズ応力の第 2 不変量

$d_{i j}^{p}:$ レイノルズ応力の圧力拡散項

$d_{i j 2}^{p *}$ ： モデル化したレイノルズ応力の圧力拡散 rapid 項

$d_{i j}$ ：レイノルズ応力の（圧力拡散を除く）拡 散項

$H ：$ 障害物高さ

$k:$ 乱流エネルギ

$\ell_{k}: \quad$ 長さスケール・ベクトル

$N u ：$ ヌセルト数

$p:$ 瞬時の圧力

$P_{i j}$ : レイノルズ応力の生成項

$R e:$ レイノルズ数

$S_{i j}: \quad$ 歪速度テンソル $\left[\partial U_{i} / \partial x_{j}+\partial U_{j} / \partial x_{i}\right]$

$U_{0}:$ 障害物上の平均速度

$u_{i}, U_{i}: \quad$ 変動速度および平均速度

$\overline{u_{i} u_{j}}$ : レイノルズ応力

$x_{i}:$ 座標軸

$\overline{u_{i} \theta}$ ： 乱流熱流束

$\delta_{i j}: \quad$ クロネッカーのデルタ

$\varepsilon, \tilde{\varepsilon}:$ 乱流エネルキの散逸率とその等方部分 $\left(\varepsilon-2 \nu \partial \sqrt{k} / \partial x_{k} \partial \sqrt{k} / \partial x_{k}\right)$

$\varepsilon_{i j}:$ レイノルズ応力の散逸率

$\phi_{i j}:$ レイノルズ応力の圧力-歪相関項

$\Pi_{i j}$ : レイノルズ応力の圧力相関項

$\Theta:$ 平均温度

$\nu ：$ 動粘性係数

$\rho:$ 流体の密度

$\tau, \tilde{\tau}: \quad$ 乱流時間スケール, $(k / \varepsilon, k / \tilde{\varepsilon})$

$\Omega_{i j}: \quad \partial U_{i} / \partial x_{j}-\partial U_{j} / \partial x_{i}$

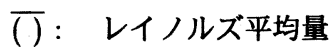

\section{2. 乱流モテル}

$2 \cdot 1$ 圧力㹡散項のモテル レイノルズ応力の輸 送方程式は一般に以下のように記述できる.

$$
\frac{D \overline{u_{i} u_{j}}}{D t}=d_{i j}+P_{i j}+\Pi_{i j}-\varepsilon_{i j}
$$

圧力相関項 $\Pi_{i j}$ は通常以下のように圧力-歪相関項 $\phi_{i j}$ と圧力拡散項 $d_{i j}^{p}$ とに分解される.

$$
\Pi_{i j}=-\overline{u_{i} \frac{\partial p / \rho}{\partial x_{j}}}-\overline{u_{j} \frac{\partial p / \rho}{\partial x_{i}}}
$$

$$
=\underbrace{\overline{\frac{p}{\rho}\left(\frac{\partial u_{i}}{\partial x_{j}}+\frac{\partial u_{j}}{\partial x_{i}}\right)}}_{\phi_{i j}}+\underbrace{\frac{\partial}{\partial x_{m}}\left(-\frac{\overline{u_{j} p}}{\rho} \delta_{i m}-\frac{\overline{u_{i} p}}{\rho} \delta_{j m}\right)}_{d_{i j}^{p}}
$$

瞬時圧力のポワソン方程式の積分式を用いて, 圧力速度相関を書けば

$$
\begin{aligned}
-\frac{\overline{u_{j} p}}{\rho}= & \underbrace{-\frac{1}{4 \pi} \int_{v o l}\left(\frac{\partial^{2} \overline{u_{k}^{\prime} u_{l}^{\prime} u_{j}}}{\partial r_{l} \partial r_{k}}\right) \frac{d V o l}{|r|}}_{\varphi_{j 1}^{p}} \\
& \underbrace{-\frac{1}{2 \pi} \frac{\partial \overline{u_{k}^{\prime}}}{\partial x_{l}^{\prime}} \int_{v o l} \frac{\partial \overline{u_{l}^{\prime} u_{j}}}{\partial r_{k}} \frac{d V o l}{|\underline{r}|}}_{\varphi_{j 2}^{p}}
\end{aligned}
$$

となる. 通常の一点相関モデルで slow 項 $\varphi_{j 1}^{p}$ 中の三 重相関を線型モデルで表し, Lumley ${ }^{(3)}$ が議論した実 現性条件を課すと

$$
\varphi_{j 1}^{p}=\frac{1}{5} \overline{u_{k} u_{k} u_{j}}
$$

と slow 項が乱流拡散項のサププロセスのようにモテ ル化できるので, 本研究でも slow 項は乱流拡散項に 含めてモデル化されているとする.

著者 ${ }^{(11)}$ は rapid 項 $\varphi_{j 2}^{p}$ は次式のようにレイノルズ 応力と長さスケール・ベクトル $\ell_{k}$ の線型関数として モデル化できると仮定して,

$$
\varphi_{j 2}^{p}=\frac{\partial \overline{u_{k}}}{\partial x_{l}} \gamma_{k}^{l j}\left(\overline{u_{l} u_{j}}, \ell_{k}\right)
$$

とした. そこで三階テンソル $\gamma_{k}^{l j}$ の眉字 $l, j$ について 対称性を満たす一般的なテンソル式はレイノルズ応力 の無次元非等方度テンソル $a_{i j}$ を用いて

$$
\begin{gathered}
\frac{\gamma_{k}^{l j}}{k}=\beta_{1} \ell_{k} \delta_{j l}+\beta_{2}\left(\ell_{l} \delta_{j k}+\ell_{j} \delta_{k l}\right)+\beta_{3} \ell_{k} a_{j l} \\
+\beta_{4}\left(\ell_{l} a_{j k}+\ell_{j} a_{k l}\right)+\beta_{5} \ell_{m} a_{k m} \delta_{j l}+\beta_{6} \ell_{m}\left(a_{l m} \delta_{j k}+a_{j m} \delta_{k l}\right)
\end{gathered}
$$

と書けるから, 式中の未知の係数 $\beta_{1} \sim \beta_{6}$ を決定する のに連続条件と TCL 条件を用いて

$$
\beta_{2}=-\frac{1}{4} \beta_{1}, \beta_{3}=\frac{3}{2} \beta_{1}, \beta_{4}=\beta_{5}=0, \beta_{6}=-\frac{3}{8} \beta_{1}
$$

が導かれた. ここで未決定の $\beta_{1}$ は応用計算を通して $\beta_{1}=-0.05$ が適切であるとされた. したがって, 提 案された圧力拡散 rapid 項 $d_{i j 2}^{p}$ のモデルは結局

$$
d_{i j 2}^{p}=\frac{\partial}{\partial x_{m}}\left(\varphi_{j 2}^{p} \delta_{i m}+\varphi_{i 2}^{p} \delta_{j m}\right)
$$




$$
\begin{aligned}
= & \frac{\partial}{\partial x_{m}}\left[\frac { \partial \overline { u _ { k } } } { \partial x _ { l } } \beta _ { 1 } k \left\{\left(\ell_{k} \delta_{j l}-\frac{1}{4}\left(\ell_{l} \delta_{j k}+\ell_{j} \delta_{k l}\right)\right.\right.\right. \\
& \left.+\frac{3}{2} \ell_{k} a_{j l}-\frac{3}{8} \ell_{m}\left(a_{l m} \delta_{j k}+a_{j m} \delta_{k l}\right)\right) \delta_{i m} \\
& \left(\ell_{k} \delta_{i l}-\frac{1}{4}\left(\ell_{l} \delta_{i k}+\ell_{i} \delta_{k l}\right)+\frac{3}{2} \ell_{k} a_{i l}\right. \\
& \left.\left.\left.-\frac{3}{8} \ell_{m}\left(a_{l m} \delta_{i k}+a_{i m} \delta_{k l}\right)\right) \delta_{j m}\right\}\right]
\end{aligned}
$$

と表すことができる.

一方, Lumley ${ }^{(13)}$ が示したように圧力相関項 $\Pi_{i j}$ を 圧力-歪相関項と圧力拡散項に分割する方法は一通り ではない.したがって，著者は以下の形式 ${ }^{(4)}(9)$

$$
\Pi_{i j}=\phi_{i j}^{*}+\underbrace{\frac{\overline{u_{i} u_{j}}}{k} \frac{d_{k k}^{p}}{2}}_{d_{i j}^{p}}
$$

が有利であることを示した. それは長さスケール・ベ クトルを

$$
\ell_{i}=\frac{k^{1.5}}{\varepsilon} d_{i}^{A}
$$

とモデル化し， $d_{i}^{A} に$ TCL SMC で使用される CraftLaunder ${ }^{(9)}$ の非一様性指標 :

$$
d_{i}^{A}=\frac{N_{i}^{A}}{0.5+\left(N_{k}^{A} N_{k}^{A}\right)^{0.5}}, N_{i}^{A}=\frac{\partial\left(A^{0.5} k^{1.5} / \varepsilon\right)}{\partial x_{i}}
$$

を用いると, 完全発達した乱流境界層では添え字 $i$ が 流れ方向を示す時 $\ell_{i}$ が 0 となるため, 式 (8) による $d_{k k 2}^{p}$ が消滅することである.つまり，式 (9)による定 義の圧力拡散項モデルは発達した壁流れ近傍では効果 を持たないことになる.一方, 既存の乱流モデルは開 発の過程で, チャネル乱流や乱流境界層で検証されて いることが通常であり, 新たに付加するモテル項がそ ういった基本的な流れ場の予測精度に影響しないとい うことはモデ開発上好都合である.したがって,

$$
d_{i j 2}^{p *}=\frac{\overline{u_{i} u_{j}}}{k} \frac{d_{k k 2}^{p}}{2}
$$

が SMC に付加される圧力拡散 rapid 項に対するモデ ル項となる.

2.2 TCL レイノルス応力方程式モデル CraftLaunder ${ }^{(9)}$ は $\phi_{i j}$ の三次 QI(quasi isotropic) モテル を基に幾何形状係数に頼らない低レイノルズ数 TCL $\mathrm{SMC}$ を開発した. そこでは圧力-歪相関項を

$$
\phi_{i j}^{*}=\phi_{i j 1}+\phi_{i j 2}+\phi_{i j 1}^{i n h}+\phi_{i j 2}^{i n h}
$$

と分解する. ここで $\phi_{i j 1}^{i n h}, \phi_{i j 2}^{i n h}$ は Craft-Launder が初 めて導入した非一様性修正項であり， $\phi_{i j 1}, \phi_{i j 2}$ を

$$
\begin{aligned}
\phi_{i j 1}= & -c_{1} \tilde{\varepsilon}\left\{a_{i j}+c_{1}^{\prime}\left(a_{i k} a_{j k}-\frac{1}{3} A_{2} \delta_{i j}\right)\right\} \\
& -c_{1}^{\prime \prime} \tilde{\varepsilon} a_{i j},
\end{aligned}
$$

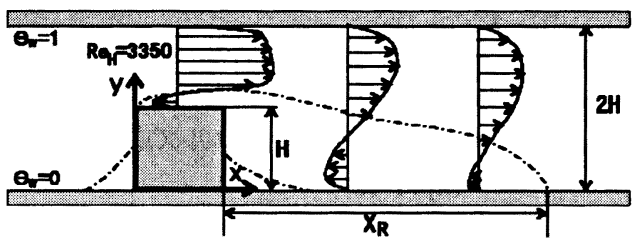

Fig. 1 Geometry of the obstacle flow.

$$
\begin{aligned}
& \phi_{i j 2}=-0.6\left(P_{i j}-\frac{1}{3} P_{k k} \delta_{i j}\right)+0.3 a_{i j} P_{k k} \\
& -\quad 0.2\left\{\frac{\overline{u_{j} u_{k}} \overline{u_{i} u_{l}}}{k} S_{k l}-\frac{\overline{u_{k} u_{l}}}{k}\left(\overline{u_{i} u_{k}} \frac{\partial U_{j}}{\partial x_{l}}\right.\right. \\
& \left.\left.+\overline{u_{j} u_{k}} \frac{\partial U_{i}}{\partial x_{l}}\right)\right\} \\
& \text { - } c_{2}\left\{A_{2}\left(P_{i j}-D_{i j}\right)+3 a_{m i} a_{n j}\left(P_{m n}\right.\right. \\
& \left.\left.-D_{m n}\right)\right\} \\
& +c_{2}^{\prime}\left[\left(\frac{7}{15}-\frac{A_{2}}{4}\right)\left(P_{i j}-\frac{1}{3} \delta_{i j} P_{k k}\right)\right. \\
& +0.1\left\{a_{i j}-\frac{1}{2}\left(a_{i k} a_{k j}-\frac{1}{3} \delta_{i j} A_{2}\right)\right\} P_{k k} \\
& -0.05 a_{i j} a_{k l} P_{k l} \\
& +0.1\left\{\left(\frac{\overline{u_{i} u_{m}}}{k} P_{j m}+\frac{\overline{u_{j} u_{m}}}{k} P_{i m}\right)\right. \\
& \left.-\frac{2}{3} \delta_{i j} \frac{\overline{u_{l} u_{m}}}{k} P_{l m}\right\} \\
& +0.1\left(\frac{\overline{u_{i} u_{l}} \overline{u_{j} u_{k}}}{k^{2}}-\frac{1}{3} \delta_{i j} \frac{\overline{u_{l} u_{m}} \overline{u_{k} u_{m}}}{k^{2}}\right) \\
& \times\left(6 D_{k l}+13 k S_{k l}\right) \\
& \left.+0.2 \frac{\overline{u_{i} u_{l}} \overline{u_{j} u_{k}}}{k^{2}}\left(D_{k l}-P_{k l}\right)\right]
\end{aligned}
$$

とモデル化する. 上式で表される三次 $\mathrm{QI}$ モテルは圧 力-歪相関項の最も一般的なテンソル式からなり, 実 現性条件を満たすように式中係数は理論的考察と基 礎流れ場での検証から与えられている. 非一様性修正 項 $\phi_{i j 1}^{i n h}, \phi_{i j 2}^{i n h}$ は従来の壁面反射項に置き換わるもので あり, 前述の非一様性指標を用いてモデル化されてい る. その後, 同じ UMIST グループの Batten ら ${ }^{(14)}$ は Craft-Launder の TCL SMC を圧縮性流れに拡張し た. 著者 ${ }^{(15)}$ は Batten らの拡張モデルを乱流熱伝達場 に応用する過程で性能上重要な修正を加えたので, 本 研究でもこの修正 TCL SMC を用いた. 詳細は既報 (15)を参照されたい.

2.3 乱流熱流束モデル 複雑な温度場の計算で は, 以下の GGDH 乱流熱流束モデル ${ }^{(16)}$ が有効であ ることが知られている(17).

$$
\overline{u_{i} \theta}=-c_{\theta} \tau \overline{u_{i} u_{j}} \frac{\partial \Theta}{\partial x_{j}}
$$




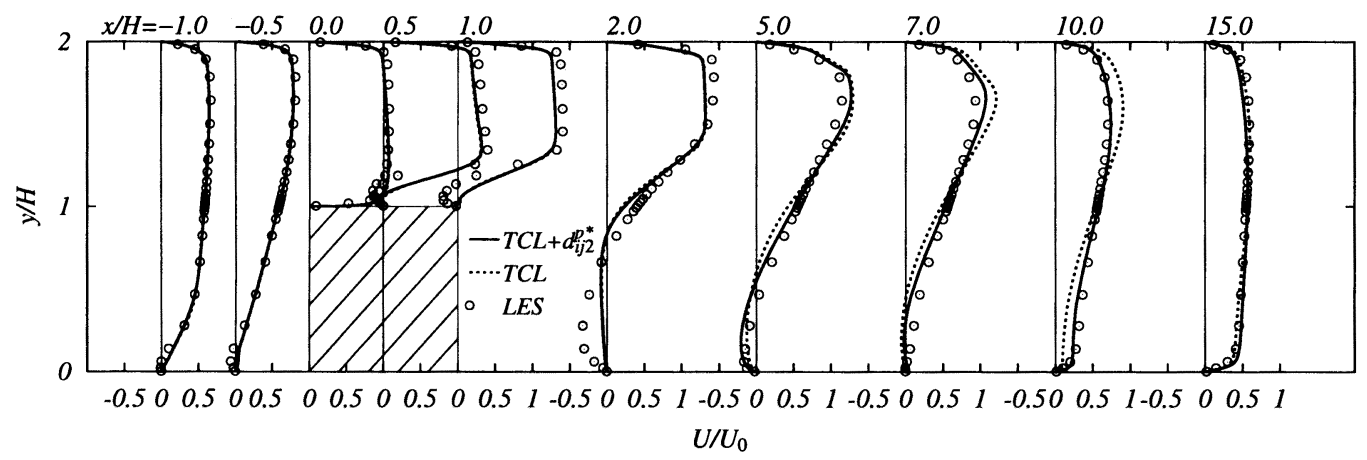

Fig. 2 Mean velocity distribution in the obstacle flow.

このモデルは SMC 等によって乱れの非等方性が精度 良く予測できる場合に有効である。 しかし，流れ方向 熱流束成分の予測については, 乱流プラントル数を用 いるモデルよりも改善はするものの, 未だ不十分であ ることも文献 ${ }^{(17)}$ に指摘されている.

この GGDH 熱流束モデルの性能を向上させるため, 著者ら ${ }^{(18)}$ は以下に示す HOGGDH（高次 GGDH 熱流 束モデ）を構築し，それが広い範囲のプラントル数 にわたり, 流れ方向熱流束成分を含めて満足な予測結 果を与えることを示した.

$$
\overline{u_{i} \theta}=-c_{\theta} k \tilde{\tau}\left(\sigma_{i j}+\alpha_{i j}\right) \frac{\partial \Theta}{\partial x_{j}}
$$

ここで対称テンソル $\sigma_{i j}$ は二次までの項を含めてモデ ル化されている.

$$
\sigma_{i j}=c_{\sigma 1} \overline{u_{i} u_{j}} / k+c_{\sigma 2} \overline{u_{i} u_{l}} \overline{u_{l} u_{j}} / k^{2}
$$

二次項は特に流れ方向の熱流束の予測に有効である. また, 非対称テンソル $\alpha_{i j}$ は,

$$
\alpha_{i j}=c_{\alpha 1} \tilde{\tau}\left(\Omega_{i l} \overline{u_{l} u_{j}} / k+\Omega_{l j} \overline{u_{i} u_{l}} / k\right)
$$

とモテル化される.

三次元 U 字管のような複雑な熱流れ場では主流方向 の熱流束成分の寄与度が増し, HOGGDH 乱流熱流束 モテルの有効性が確認されている(19) (20). TCL SMC と組み合わせた場合の係数の詳細については, 既報 ${ }^{(15)}$ を参照されたい.

\section{3. 結果および考察}

計算は全て著者ら ${ }^{(21)}$ が開発した非構造格子プログ ラムにて行った，そこでは圧力解法に PISO 法 ${ }^{(22)}$ 用い, 対流項の差分には 3 次精度 MUSCL 型の手法 (23)を用いている.
解析した流れ場は Yang-Ferziger ${ }^{(12)}$ の DNS で行わ れた二次元障害物流れである. 図 1 に示すように高さ $2 H$ の二次元チャネルの下面に正方形の障害物を置いた もので, 障害物上面のバルク平均流速 $U_{0}$ 之障害物高さ $H$ を基にした $R e \cdot=3350$ の流れである. DNS の解析 領域が障害物を含む流れ方向全長 $31 H$ の周期境界で繋 がれたものであるので，本解析もこれに従った．計算 格子は総数 20660 の矩形要素を壁面近傍で緻密になる (全ての壁面第 1 格子点が $y^{+} \simeq 0.09^{1 / 4} k^{1 / 2} y / \nu<1$ に配置されている.）ように不等間隔に配置したもの で, 解の格子依存性が議論に影響しないことを各方向 2 倍の格子点を持つ別の細格子による結果と比較する ことで確認している. (両者の障害物後方の再付着点距 離は誤差 $2 \%$ 以内で一致している.)

Yang-Ferziger ${ }^{(12)}$ の DNS は公表されたデータが十 分ではなく, かつ温度場の解析はなされていないので, 実際の比較には著者ら ${ }^{(24)}$ が同じ流れ場で温度を含め たLES（ラージ・エティ・シミュレーション）を別途に 行っているので, その結果を使用した. 温度場の解析は $P r=0.71$ の空気流を対象とし, 上壁温度: $\Theta_{w}=1.0$, と障害物を含めた下壁の温度: $\Theta_{w}=0.0$, はそれぞれ 一定とする条件を課した.

3.1 流れ場 図 2 に流れ方向平均速度分布を比 較する. 障害物の上流側に現れる剥離泡の剥離点が DNS では $x / H=-1.5$ であるのに対し, TCL SMC では $x / H=-0.43$ となるが, 付加項 $d_{i j 2}^{p *}$ はこれに 対し何の影響も与えていない. また, 障害物の上や背 後の逆流の大きさにも影響が見られないが，付加項は $5.0 \leq x / H$ の領域で速度分布を改善している. そのた め, 障害物後方の再付着点距離は $X_{R} / H=7.2$ から $X_{R} / H=6.2$ に改善される. (DNS は $X_{R} / H=6.4$ で ある.） 


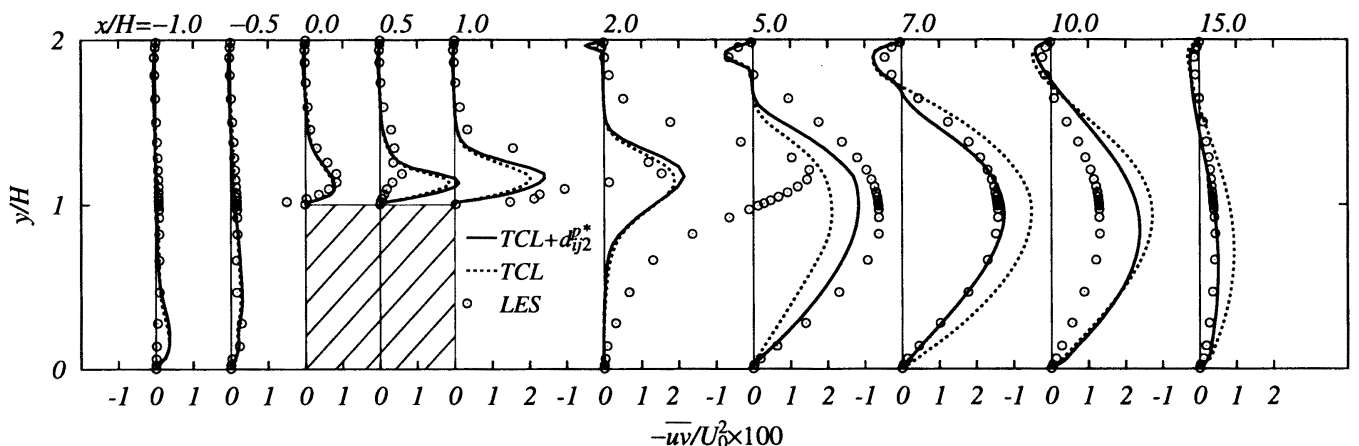

(a)

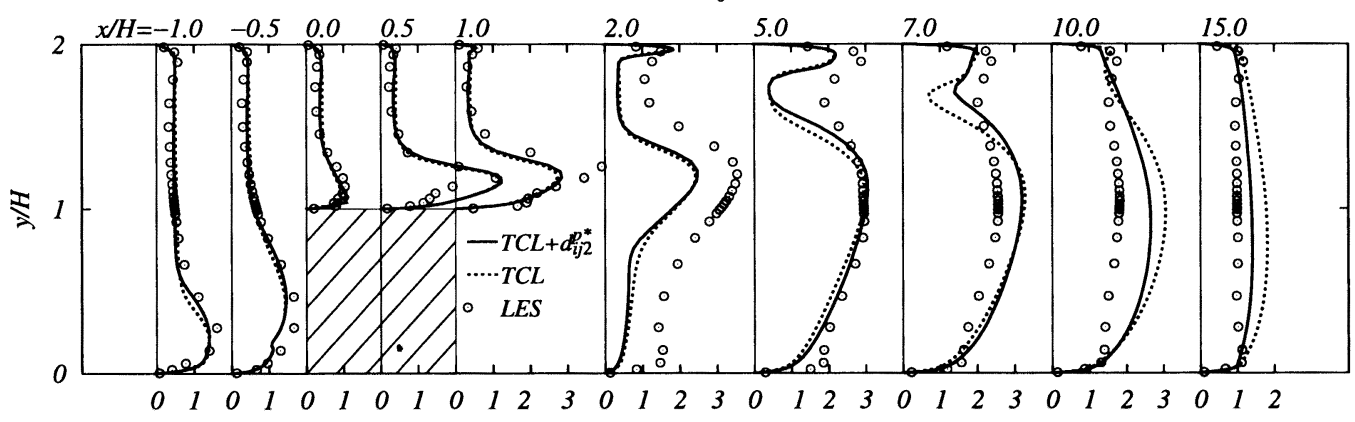

(b) $\sqrt{u^{2}} / U_{0} \times 10$

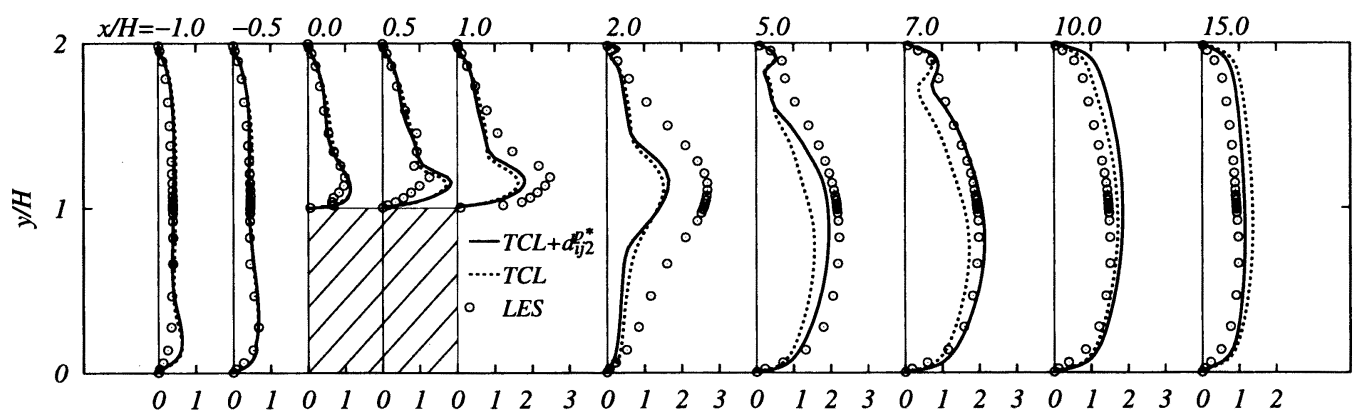

(c) $\sqrt{v^{2}} / U_{0} \times 10$

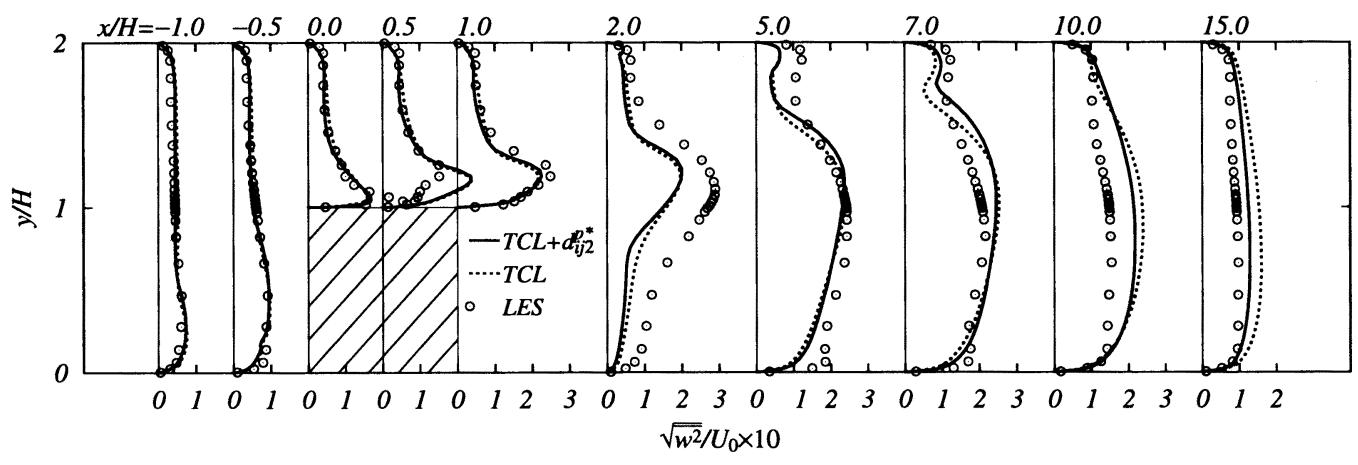

Fig. 3 Reynolds stress distribution in the obstacle flow. 


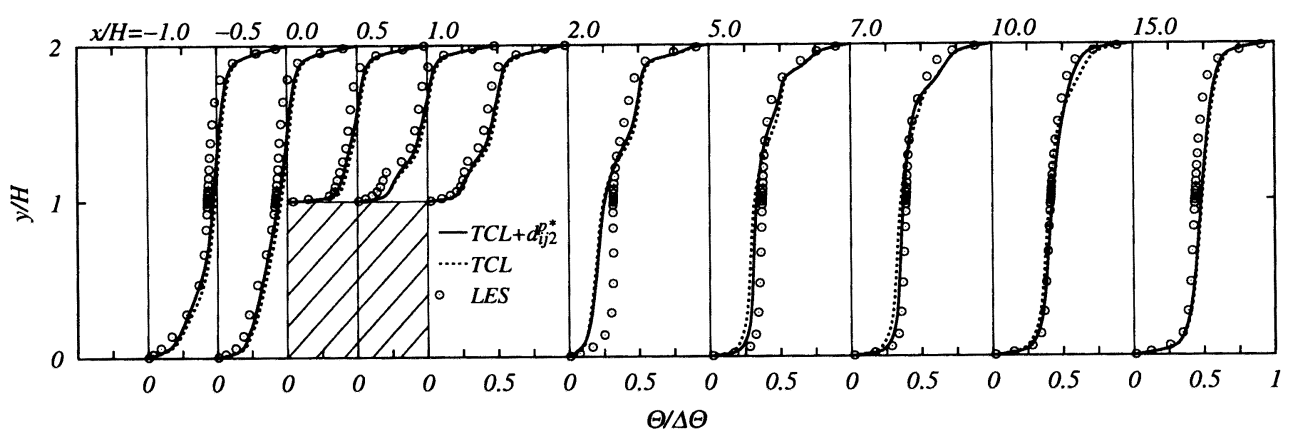

Fig. 4 Temperature distribution in the obstacle flow.

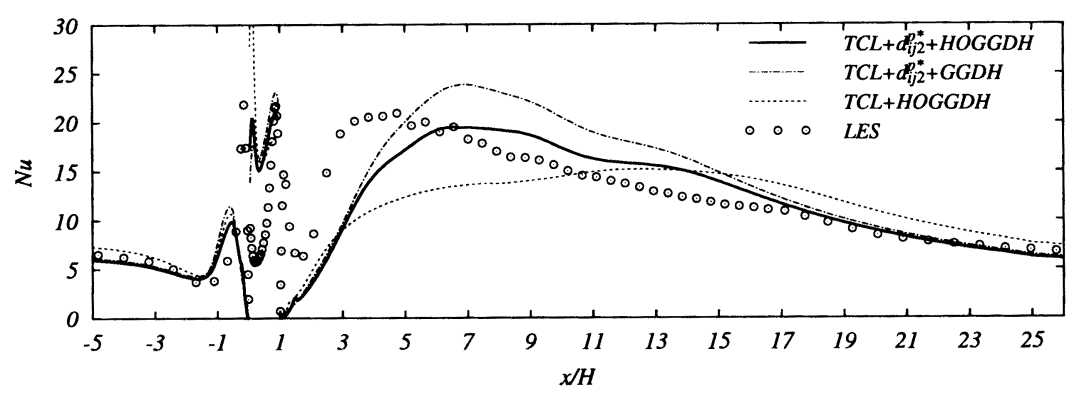

Fig. 5 Local Nusselt number distribution along the bottom plane.

平均速度場に呼応して図 3(a)に示すように, レイ ノルズせん断応力 $-\overline{u v}$ も付加項 $d_{i j 2}^{p *}$ によって特に $5.0 \leq x / H$ の領域で改善される. しかしながら, $x / H=2.0$ の断面では大きな改善が見られない. 付 加項があってもなくても TCL SMC は障害物の上面 $(x / H=0.5)$ で $-\overline{u v}$ を過大予测するにもかかわらず $1.0 \leq x / H \leq 2.0$ では過小予測をしている.この傾 向は, 図 3(b)(c)(d) に示すその他のレイノルズ応力 の分布にも見られる. やはり, 付加項の影著な効果は $5.0 \leq x / H$ の領域に限って見られる. このことが平均 速度分布に影響し, 先の再付着点位置の予測改善に㪙 がっていると考えられる.

レイノルズ応力方程式の生成項 $P_{i j}=$ $-\left(\overline{u_{i} u_{k}} \partial U_{j} / \partial x_{k}+\overline{u_{j} u_{k}} \partial U_{i} / \partial x_{k}\right)$ や式 (15) の圧 力 - 歪相関項の rapid 項 $\phi_{i j 2}$ は, 平均歪速度が 0 に なるとやはり 0 になる. したがって, 図 Fig.3(b) の $x / H=2.0,5.0,7.0$ の断面の上壁近傍で顕著なよう に, $\overline{u^{2}}$ 等の分布は速度の極大值に呼応して大きな䇠 みを持つ. 付加項 $d_{i j 2}^{p *}$ がない場合, 窪みは大きすぎる が $x / H=7.0$ の断面では付加項によって改善される. これは, 式(8) から分かるように, 圧力拡散 rapid 項 は速度の極大值の位置でも 0 とはならない速度の二
階勾配に依存するからである.

以上に示されるようにモデル化された圧力拡散 rapid 項は主に再付着点付近から下流域で効果を持つが, 特 に $x / H=2.0$ の循環流域での予測改善には期待され た効果がない. もちろん散逸項や他のモデル項にも再 検討の余地があろうが, 本研究で着目している圧力拡 散項に関しては, 陰的に乱流払散項に含まれるとして 特に考慮をしていない slow 項のモデルと式 (12) によ る圧力拡散項の再定義をさらに検討する必要があると 考えられる. 特に構造パラメータの比例関係を用いて 再定義する式 (12) のモデルは, 文献 ${ }^{(4)}$ に示されるよ うにチャネル乱流の壁近傍に於ける圧力相関項のモテ ル化に有利である一方で, 壁面垂直応力 $\overline{v^{2}}$ の圧力拡 散をチャネル乱流では本来の圧力拡散 (式 $(2)$ 中 $d_{i j}^{p}$ ) が 0 となる応力成分 $\left(\overline{u^{2}}, \overline{w^{2}}\right)$ にも分配することから, 結果的に圧力拡散の非等方分布を緩和させる働きを する. したがって, 同様のことが剥離せん断層でも起 こると考えられるので, 式 (8) で提案された圧力拡散 rapid 項をそのまま SMC に組み込む方が, $\overline{v^{2}}$ の分布 に圧力拡散の効果をより反映できると考えられる. そ れが $\overline{u v}$ の生成 $\left(\sim-\overline{v^{2}} \partial U / \partial y\right)$ に影響を与えることに なるので, 循環流域での $-\overline{u v}$ の予測改善に効果的で 


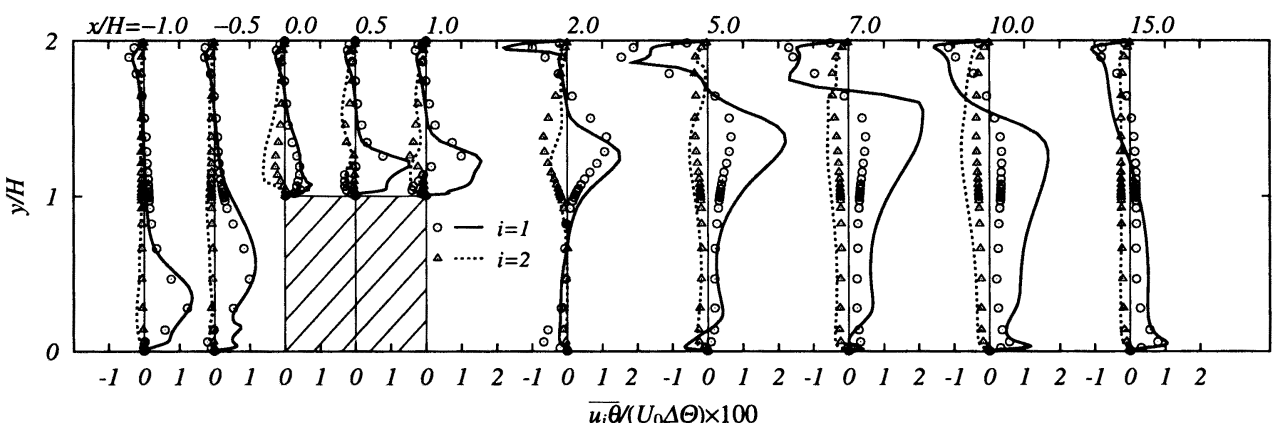

(a)

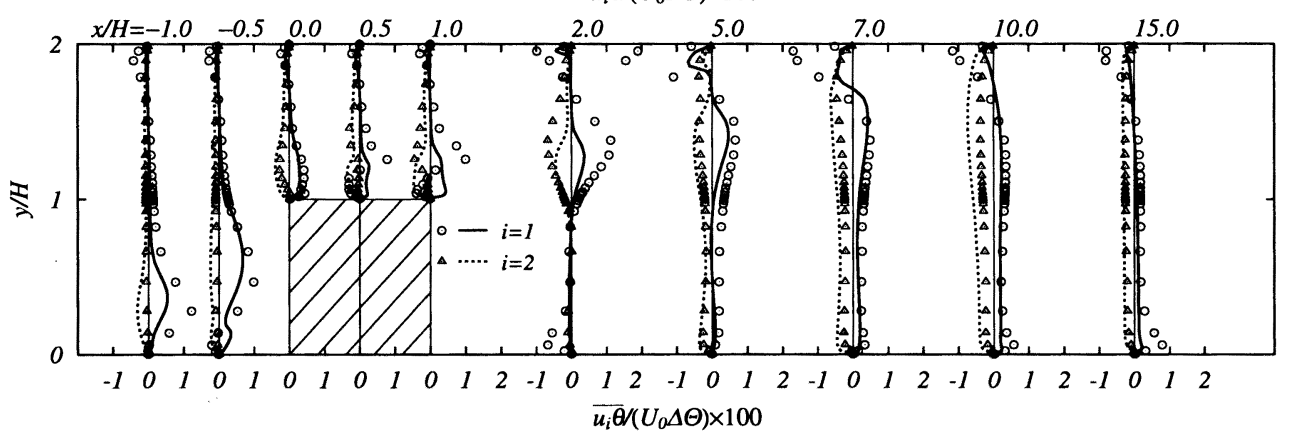

Fig. 6 Turbulent heat flux distribution in the obstacle flow; symbols:LES, lines:TCL SMC with the rapid pressure-diffusion; (a): HOGGDH, (b): GGDH.

ある可能性がある. しかしその場合には, 式 (8) を導 入したモデル本体を境界層等の基本流れから再検証し 再チューニングする必要が生じる.

3.2 温度場 図 4 に温度場のモデルに HOGGDH 乱流熱流束モテルを用いた場合の平均温度分布 を比較する. 付加項 $d_{i j 2}^{p *}$ のあるなしにかかわらず, 速 度場に呼応して $x / H=2.0$ では不十分だが, 全体的 には LES のデータと妥当な一致を示す. そして, 付 加項のある方が特に $x / H=5.0,7.0$ の断面の下壁近 傍で若干良い結果を与えることが分かる. この改善が 次に議論する壁面熱伝達率の予測結果に大きく影響を 及ぼす。

図 5 は下壁上の局所ヌセルト数 $N u$ の分布を比較し たものである. 明らかに速度場同様, 付加項によって 障害物後方の領域で予測精度に差が出ている. これは 再付着点を含む $5.0 \leq x / H \leq 10.0$ の領域で, 図 3(c) に示されるように特に壁面近傍の壁面垂直応力 $\overline{v^{2}}$ の予 測精度が向上していることに起因している. しかしな がら, 障害物のすぐ背後の領域では図 3 の $x / H=2.0$ の断面で明らかなように乱れ量の分布が過小予測であ るため, どの予測結果も $N u$ を過小評価する. また, 障害物上面では $x / H=0.5$ の断面で乱れ量の過大予
測に従い, $N u$ も過大予測となっている.

なお，障害物後方の領域で HOGGDH 乱流熱流束 モデを用いた方が標準の GGDH の結果より優れて いることは明らかである. (GGDH を用いる場合, 標 淮の係数 $c_{\theta}=0.3$ を用いた. 標準係数で満足な值を得 ることは円管乱流等で別途確認している.)

図 6 にHOGGDH とGGDH による乱流熱流束の分 布を示す. 図6(a) に示されるように HOGGDH は流 れ方向成分 $(i=1)$, 壁面垂直成分 $(i=2)$ ともに全 般的には妥当な結果を示していると言える. ただし, $x / H=5.0,7.0,10.0$ のチャネル中央領域で流れ方向成 分は過大予測される傾向にある. また, 障害物上面壁 近傍で流れ方向成分の符号が逆転する様子もとらえら れていない等の欠点が認められる. GGDH の場合は壁 面垂直成分については HOGGDH と同様の傾向だが, 流れ方向成分については特に壁面近傍で過小である.

再付着点近傍では $U$ の符号の変化に伴い, 図 6 に示 されるように流れ方向の熱流束の符号も負から正に変 化する. よって, エネルギ式中の項 $-\frac{\partial}{\partial x}(\overline{u \theta})$ も一定 の負のレベルを保持する. その結果, 図 5 に示される ように, 壁面近傍の流れ方向熱流束を妥当なレベルで 予測する HOGGDH の方が，そうでない GGDH より 
小さな值で妥当に $N u$ 分布を予測すると考えられる.

\section{4. 結言}

本研究では著者が以前に開発した圧力拡散 rapid 項 モデルを TCL レイノルズ応力方程式モデルに組み込 み, 二次元障害物周りの熱流れ場でその効果につい て議論した. また, 温度場のモテルに標準と高次の GGDH 乱流熱流束モデルを用い, 熱流束モテルの効 果についても議論した. 以下に結論をまとめる.

(1) 圧力拡散 rapid 項のモデルは TCL レイノルズ応 力方程式モデルに付加することで, 障害物後方で予測 結果を改善する. 特に再付着点より少し上流から下流 にわたって乱れ場の回復を改善する. しかし, 障害物 前方の衝突流れ領域や, 障害物直後の逆流域では顕著 な影響を示さず, 予測性能を改善しない.

(2) 付加項は再付着点付近から乱れのレベルを改善す るので, 壁面熱伝達率の予測精度が向上する.

(3) 高次の GGDH 熱流束モテルは, 再付着点付近の 壁面近傍で流れ方向熱流束成分を妥当なレベルで予测 するため, 結果として壁面熱伝達率の予測精度も良い.

\section{文献}

(1) Yao,Y.F., Thomas, T.G., Sandham, N.D., Williams, J.J.R., Theore. Comput. Fluid Dynamics, 14 (2001), 337-358.

(2) Hanjalić, K., Obi, S. (editors), Proc. The sixth ERCOFTAC/IAHR/COST Workshop on Refined Flow Modelling, TU Delft, The Netherlands (1997).

(3) Lumley, J.L., Adv. in Applied Mech., 18 (1978), 123-176.

(4) Mansour, N.N., Kim, J., Moin, P., J. Fluid Mech., 194 (1998), 15-44.

(5) Spalart, P.R., J. Fluid Mech., 187 (1988), 61-98.
(6) Yoshizawa, A., Phys. Fluids, 30 (1987), 628-631.

(7) Kawamura, H., Kawashima, N., Proc. Int. Symp. on Turbulence, Heat and Mass Transfer, Lisbon, Vol.2 (1994),P.I.1.1-P.I.1.4.

(8) Nagano, Y., Shimada, M., JSME Int. J. B, 38 (1995), 51-59.

(9) Craft, T.J., Launder, B.E., Int. J. Heat Fluid Flow, 17 (1996), 245-254.

(10) Yoshizawa, A., Phys. Fluids, 14 (2002), 1736-1744.

(11) 須賀一彦, 機論, 70-697, B (2004), 2386-2393.

(12) Yang, K.-S., Ferziger, J.H. , AIAA J., 31 (1993), 1406-1413.

(13) Lumley, J.L., Phys. Fluids, 19 (1975), 750.

(14) Batten, P., Craft, T.J., Leschziner, M.A., Loyau, H., AIA A J., 37 (1999), 785-797.

(15) 須賀一彦, 機論, 68-668, B(2002), 1206-1213.

(16) Daly, B.J., Harlow, F.H., Phys. Fluids, 13 (1970), 2634-2649.

(17) Launder, B.E., ASME J. Heat Transfer, 110 (1988), 1112-1128.

(18) Suga, K., Abe, K., Int. J. Heat Fluid Flow, 21-1 (2000), 37-48.

(19) Suga, K., Int. J. Heat Mass Transfer, 46 (2003), 161-173.

(20) Suga, K., Nagaoka, M., Horinouchi, N., ASME J. Heat Transfer, 125-1 (2003), 200-203.

(21) Suga, K., Nagaoka, M., Horinouchi, N., Abe, K., Kondo, Y., Int. J. Heat Fluid Flow, 22-3 (2001), 259-271.

(22) Issa, R., J. Comput. Phys., 62 (1985), 40-65.

(23) van Albada, G.D., van Leer, B., Roberts, W.W., Astronomy and Astrophysics, 29-7 (1991), 10921110.

(24) Abe, K., Suga, K., Heat Transfer Asian Res., 30 (2001), 402-418. 